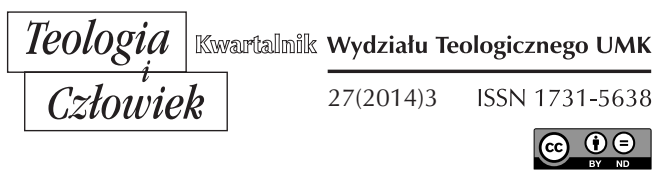

ELŻBIETA WASYŁYK*

SZCZECIN

\title{
SYMPTOMY PERSONALIZACJI SZTUKI
}

DOI: http://dx.doi.org/10.12775/TiCz.2014.042

Stawianie pytań i szukanie odpowiedzi przez analogie jest tak znamienną ludzką aktywnością intelektualną, że również dzisiaj nie sposób oprzeć się chęci poszukiwania podobieństw między poszczególnymi okresami w personalistycznej wizji wszechświata Teilharda de Chardin a zmianami sposobu widzenia $\mathrm{w}$ przestrzeni sztuki, od prehistorii po współczesność. Od kubizmu wyraźnie uwydatniła się nie tylko subiektywność podmiotu twórczego, ale intrasubiektywność z nieograniczonym zasobem wytworów wirtualnych. Wyczuwalny w historii sztuki kierunek - od przedmiotu, czyli przez opisywanie rzeczywistości za pomocą tego wszystkiego, co rzeczywiste, zewnętrzne - do podmiotu, czyli wyrażanie stanu wewnętrznego, związanego z treścią świadomości, wprowadza $\mathrm{w}$ tezę, że w przestrzeni polskiej sztuki współczesnej, wraz ze zwrotem nie tylko w stronę podmiotu twórczego, ale „w stronę osoby”, można zauważyć symptomy nowej jakościowo dynamiki estetyczno-ducho-

* Elżbieta Wasyłyk - malarka, dr hab., prof. Akademii Sztuki w Szczecinie. Prowadzi II Pracownię Malarstwa i Rysunku na Wydziale Sztuk Wizualnych i pełni funkcję kierownika Katedry Przedmiotów Ogólnoplastycznych i Teoretycznych AS. W 2007 roku obroniła pracę doktorską w dziedzinie malarstwa na Wydziale Sztuk Pięknych UMK w Toruniu, a w 2011 roku pracę habilitacyjną na ASP w Krakowie. 
wej, którą nazywam „personalizacją sztuki” i która wypływa bardziej z podstaw metafizyki judeochrześcijańskiej niż greckiej, niewątpliwie stanowiącej z pierwszą dwugłos europejskiej cywilizacji u jej początku.

Problem „personalizacji sztuki” zarysował się dla mnie w kontekście teorii Teilharda de Chardin ${ }^{1}$. Ukazuje ona proces przenikający życie wszechświata, który prowadzi do jedności, jednakże nie przez ujednolicenie elementów, które jednoczy, ale przez różnicowanie ich, bo to ,jedność różnicuje". Proces ów de Chardin nazwał personalizacją. Jest ona siłą dynamizmu ludzkiego rozwoju, który stawia człowieka wobec konieczności pogłębiania istoty i udzielania się temu, co na zewnątrz. Znamienny jest fakt, że żyjemy w czasach niezwykłej, nie tylko artystycznej, różnorodności, a szybkość komunikacji fizycznej oraz przepływu informacji coraz bardziej scala nas jako ludzkość. De Chardin podzielił rozwój wszechświata na kilka faz. Po fazach: ożywienia i psychizacji nastąpił okres, w którym pojawiła się na ziemi istota myśląca - to okres hominizacji. Czwarty, ostatni etap rozwoju wszechświata to personalizacja. W niej uwydatnia się bardziej duchowy niż witalny obraz człowieka. Analizując historię sztuki europejskiej pod względem dominujących $\mathrm{w}$ niej treści i form plastycznych, można zauważyć, że $\mathrm{w}$ niektórych okresach dominuje ludzka witalność (cielesność i psychika), a w innych duch, który stara się przebić sferę doświadczeń czysto ludzkich, humanistycznych i ukazać doświadczanie tego, co poza doświadczeniem empirycznym, poza kanonami kultury. José Ortega y Gasset, analizując historię sztuki, wykreślił dwa kierunki jej rozwoju. Pierwszy zakłada ruch od tego, co widziane z biska, dokładnie, rzeczowo (np. malarstwo wczesnego renesansu), do tego, co widziane z daleka (np. impresjonizm) i co w swym ogólnym założeniu optycznym staje się rodzajem wizualnej demokracji. Drugi kierunek, niejako zwrotny, ukazuje ruch w kierunku od przedmiotu do podmiotu. Obraz zatrzymuje się nie tylko na siatkówce oka, ale wnika głęboko, poza nią i ostatecznie wyraża bardziej stan wewnętrzny twórcy niż potrzebę mimetycznego przedstawiania rzeczywistości zewnętrznej. W ten sposób twórca ma możliwość akcentowania swojej podmiotowości już nie tylko psychologicznie, ale również duchowo. Człowiek jest duchomaterią; duchem i witalnością (ciałem i duszą) i w zależności od tego którą sferę angażuje bardziej w proces twórczy, powstaje sztuka o znamionach humanizmu, personalizacji bądź depersonalizacji. Ortega y Gasset zauważył, że w okresie gotyku, renesan-

${ }^{1}$ T. de Chardin, Zarys wszechświata personalistycznego, Warszawa 1985. 
su i w XIX wieku dominowała w sztuce dusza, aspekt witalny, typowo ludzki, głęboko humanistyczny, natomiast w okresie baroku przewagę zyskał duch. Z witalną aktywnością twórczą można połączyć aktywność ludzką, która przypomina odyseję, wędrówkę po śladach wspomnień, do tego, co już było, co znane. Natomiast twórczość wyrażająca aktywność ducha przypomina wyjście z Ur; wędrówkę abrahamową; w nieznane; po ścieżce Głosu, który wzmaga pragnienie duchowe i nieustannie ożywia.

Współczesna sztuka jest niezwykle różnorodna i treściowo, i formalnie. Poprzedzają ją trzy istotne przełomy, które stworzyły niejako techniczne podłoże dla głęboko personalnej aktywności twórczej. Pierwszy przypadł na czas antyku greckiego i zapoczątkował okres przemian, których ukoronowaniem stał się humanizm doby renesansu wyrażający człowieka jako panującego nad światem. Drugi to tzw. pierwsza awangarda z początku XX wieku, która dokonała dehumanizacji sztuki. Trzeci przypadł na czas postmodernizmu, poprzedzonego depersonalizacją sztuki. Wszystkie one zapracowały na sytuację obecną bądź to przez negację, bądź przez rodzaj afirmacji postaw estetycznych i duchowych, które funkcjonują we współczesnej przestrzeni symbolicznej ukazującej pośrednio i bezpośrednio człowieka nie tylko rozdartego, ale także śmiertelnie zranionego. U schyłku renesansu człowiek zaczął wytracać poczucie filozoficznej równowagi. Odkrycia naukowe wciąż intensyfikują ten proces, który pogłębia poczucie rozdarcia między, tym kim człowiek jest, a kim być powinien. Schyłkowy okres twórczości Michała Anioła, dynamiczna forma barokowa i dramatyczne barokowe chiaroscuro, gwaltowność romantyczna i "rozbite lustro kubizmu” zdają się tłumaczyć stwierdzenie Arthura Rimbaud, który mawiał o sobie: ,ja - to kto inny". Michał Anioł w ostatnim okresie swojej twórczości wyszedł poza formę aktu klasycznego, która jest nośnikiem idealizmu w sztuce. Figury proroków z Kaplicy Sykstyńskiej zaprzeczają wierze w dające się wymierzyć proporcje. Emanuje z nich przeczucie nowej jakości życia, która wymyka się matematycznej logice obrazu. Problem człowieka, proroka - łącznika między światem ziemskim i pozaziemskim - został ukazany w perspektywie bardziej dynamicznej niż równowaga humanizmu. Janusz St. Pasierb, analizując wypowiedź Rimbaud, zauważył, że nie chodzi w niej o rozdarcie między dobrem a złem, które człowieka nigdy nie opuszczało, ale o to, co św. Paweł ujął w kształt dylematu: człowiek cielesny i człowiek duchowy ${ }^{2}$. Zachwianie poczucia tożsamości, a może więcej - totalny

2 J. St. Pasierb, Pionowy wymiar kultury, Kraków 1983, s. 7-8. 
jej brak - widać w wizerunkach „strzępów form ludzkich” w obrazach Francisa Bacona. To samo egzystencjalne rozdarcie widać w twórczości polskich artystów okresu nowej figuracji, zwłaszcza w obrazach Zbyluta Grzywacza. Nowe media, operujące efektem szybkiego obrazu mechanicznego, digitalnego i wirtualnego, nurt krytyczny oraz nurt sztuki feministycznej wyznaczają tendencje w sztuce współczesnej i zmieniając optykę widzenia, wprowadzają jedynie pozory bliskości problemom człowieka, nie przywracając mu poczucia równowagi. Człowiek wciąż się boi, a jego lęk wyraża się ucieczką w zachowania infantylne, agresywne i przesadnie konsumenckie, żyje częściej cudzym życiem, życiem kreowanym przez media. Cierpi na brak perspektywy eschatologicznej. Funkcjonuje w modelu kultury, w której dominuje aspekt cielesny do tego stopnia, że coraz bardziej jałowiejący przekaz wizualny karmi odbiorcę jedynie rzeczami zużytymi; ready mades. Proces twórczy stał się tak bardzo cielesny, że aż obrazoburczy. Sztuka, w której od renesansu człowiek zajmował wyjątkową pozycję, w XX wieku została pozbawiona nie tylko jego wizerunku jako wiodącego motywu, ale została pozbawiona wyczuwalnego w niej jego istnienia poprzez myśl porządkującą dzieło ${ }^{3}$. Tego typu sytuacja nie pojawiła się nagle. Analiza zmian, jakie zachodzą w sztuce europejskiej od czasów renesansu po współczesność, pozwala lepiej zrozumieć ten problem. Humanizm renesansowy stworzył taką formę człowieka w sztuce, która ukazała go jako tego, który przeniknięty siłą i spokojem panuje nad światem. Antoni Maśliński upatruje w kontrapoście formę, która najpełniej wyraża humanizm w sztukach przedstawieniowych ${ }^{4}$, a Kenneth Clark, analizując formę rzeźby greckiej okresu antycznego, która inspirowała renesans artystyczny, podkreślił fakt, że jest ona wyrazem nie tylko matematycznego porządku kształtującego doznania zmysłowe, ale także łagodzi nieokreślone lęki przed nieznanym, ukazując bogów jako ludzi ${ }^{5}$. Rozwój myśli humanistycznej doprowadził w XIX wieku do monistycznego traktowania człowieka, pozbawionego nadprzyrodzoności. Tendencje naturalistyczne w sztuce korespondowały z pozytywistycznym nurtem filozoficznym i w pewnym sensie były wynikiem ograniczenia człowieka do jego zmysłowości, uczuciowości i empiryczności, które stały się sposobem satysfakcji, a patos próbował zastąpić fundamentalną potrzebę duchowego przeżycia. Mikołaj Bierdiajew dowodził, że ostat-

3 Tamże.

4 A. Maśliński, Humanizm w sztuce. Antyk i człowiek, Kraków 1978.

${ }^{5}$ K. Clark, Akt. Studium formy idealnej, Warszawa 1998, s. 26. 
nim etapem humanizmu był materialistyczny socjalizm Karola Marksa, który doprowadził humanizm do negacji człowieka, „do ostatecznego zniewolenia przez determinizm, do przekształcenia człowieka w narzędzie materialnych sił produkcji - podkreślił, że - kłębek wrażeń, zmiana odczuć" są jedynie drobną cząstką mechanizmu przyrody, a nie całym człowiekiem $^{6}$. Ten kontekst jest niezwykle ważny, ponieważ uwydatnia sens i znaczenie humanizmu, a potem dehumanizacji, depersonalizacji i personalizacji w sztuce.

Dehumanizacja i depersonalizacja brzmią dramatycznie, ale znaczenie tej pierwszej dla sztuki nie jest złowrogie. Awangarda dwudziestowieczna, która stanęła $\mathrm{w}$ opozycji do realizmu, sentymentalizmu, patosu i dosłowności sztuki XIX wieku, zwróciła uwagę na wartości estetyczne. Akt awangardowej negacji treści humanistycznych w sztuce, które wiążą się ze zmysłowym sposobem przeżywania rzeczywistości, $\mathrm{z}$ wprowadzaniem w przeżywanie tylko tego, co dobrze znane, co kieruje podziw ku człowiekowi, jego cielesności, czyli w immanencję ludzkiego świata, Ortega y Gasset nazwał dehumanizacją. Dehumanizacja sztuki wyrwała człowieka ze schematów myślowych, estetycznych i zmysłowych i wyprowadziła go poza, można powiedzieć, że w przestrzeń wolności estetycznej i tematycznej. Pytanie postawione przez Ortegę y Gasseta: "Co znaczy ten wstręt do elementu ludzkiego w sztuce? Czy jest to niechęć do wszystkiego, co ludzkie, czy też odwrotnie?"7 stanowi ożywczy impuls do dalszej refleksji. Dehumanizacja umożliwiła rozumienie sztuki jako języka opisującego problemy, które trudno wyrazić kategorią jedynie mimetyczną, przestrzenią obrazu budowanego z jednego, nieruchomego punktu widzenia. Pozytywne znaczenie dehumanizacji sztuki nie uchroniło jej przed depersonalizacją.

Awangarda amerykańska przeniosła dzieło sztuki, jak pisał Andrzej Osęka, „z górnych, metafizycznych rejonów wyobraźni - w rejony niższe, przyziemne, konkretne" ${ }^{\prime \prime}$. Pop-art pełen ironii, powierzchowności, konsumpcjonizmu i seksualności utrwalił nie tylko determinizm przyrody w człowieku, ale przede wszystkim mechanizmy uniemożliwiające jego transcendowanie. Alicja Kępińska podkreśliła fakt, że pop-art szczególnie zrywał z psychologiczną nośnością dzieła sztuki, które przestało być autobiograficznym zapisem osobowości i stało się bezosobowym wyra-

\footnotetext{
${ }^{6}$ M. Bierdiajew, Sens twórczości, Kęty 2001.

7 J. Ortega y Gasset, Dehumanizacja sztuki i inne eseje, Warszawa 1980.

8 A. Osęka, Spojrzenie na sztukę, Warszawa 1987, s. 239.
} 
zem9. Współcześnie wśród różnorodnych postaw w sztuce rozwija się nurt niszowy, który w pewnym sensie wyrasta ideowo $\mathrm{z}$ doświadczeń sztuki niezależnej lat 80. XX wieku przez kontynuację kierunku „w stronę osoby", któremu bliski jest obraz ukazujący człowieka jako szczególną wartość, osobę wykraczającą poza naturę i historię. Ten nurt został nazwany przez Tadeusza Borutę personalizmem.

Personalizm w polskiej sztuce wyrasta przede wszystkim ze środowiska myśli chrześcijańskiej. Istnieje jednak wiele postaw artystycznych, które nie utożsamiając się z tą myślą bezpośrednio, prowokują jednak swoją aktywnością do stawiania pytań fundamentalnych i w rzetelny sposób szukają na nie odpowiedzi. Zainteresowanie podmiotowością, tendencja "w stronę osoby", wyraża się określoną dynamiką ideowo-estetyczną w dziedzinie sztuki, którą można nazwać „personalizacją sztuki”. Rozróżnienie na „personalizm w sztuce polskiej” i „personalizację sztuki" jest ważne dla tej pracy. Personalizm w polskiej sztuce stanowi jeden z nurtów sztuki współczesnej, który jest symbiotycznie związany ze środowiskiem kultury chrześcijańskiej przenikniętej filozofią personalną. Natomiast personalizacja sztuki jest zjawiskiem bardziej rozległym, niekoniecznie związanym ze środowiskiem chrześcijańskim bezpośrednio. Jest konsekwencją takiej aktywności artystycznej, w której dominuje problematyka związana z podmiotowym podejściem do człowieka, niekwestionująca jego duchowo-materialnej konstrukcji. Niszowa tendencja w sztuce polskiej, związanej z personalizacją sztuki, która została szarzej omówiona w mojej pracy habilitacyjnej: Personalizm w malarstwie polskim. Symptomy personalizacji sztuki, pozwala zauważać ciągły kierunek „w stronę osoby", sięgający korzeniami aż do okresu Młodej Polski, kiedy to został stworzony naturalny pomost między światem sztuki i religii. Dla patriotycznie nastawionych i żyjących treściami chrześcijaństwa wybitnych postaci malarstwa tego okresu: Stanisława Wyspiańskiego, Józefa Mehoffera, Eligiusza Niewiadomskiego, a przede wszystkim dla Jacka Malczewskiego - „twórczość sakralna stała się możliwością najpełniejszego wyrażenia swej artystycznej indywidualności. Dzięki temu stworzyli oni dzieła liczące się w skali europejskiej"10. Drugi etap prowadzący do kształtowania się tendencji personalnej w polskiej sztuce wiąże się z twórczością niektórych arsenałowców, np. Andrzeja Wróblewskiego,

9 A. Kępińska, Nowa sztuka. Sztuka polska w latach 1945-1978, Warszawa 1981, s. 31-32.

${ }^{10}$ W. Skrodzki, Polska sztuka religijna 1900-1945, Warszawa 1989, s. 25. 
Jana Lebensteina, Aliny Szapocznikow czy też Andrzeja Strumiłły, którzy przyjmując postawę buntowniczą i otwartą, „pragnęli komunikować prawdę, a nie schematy"11. Niektórzy polscy neofiguraliści lat 60 . zaczęli łączyć w swojej sztuce to, co estetyczne, z tym, co etyczne. Pojawił się zatem już nie tylko powrót do postaci człowieka, ale także do głębszych refleksji nad osobą. Szczególną rolę w nurcie „nowej figuracji” odegrała krakowska grupa Wprost, której członkowie podjęli znaczące refleksje na temat kondycji człowieka również w czwartym etapie dojrzewania myśli personalnej w sztuce polskiej, czyli w okresie stanu wojennego. Problematykę tego etapu opisywała Renata Rogozińska:

Człowieka zaczęto postrzegać już nie tylko jako bryłę w przestrzeni, pewien kształt osadzony $\mathrm{w}$ widzialnej rzeczywistości, stwarzający ogromne możliwości formalnych manipulacji. W centrum zainteresowania znalazła się ludzka podmiotowość, a także dramatyczne problemy współczesności. Po szaleńczym pościgu nowości, unicestwianiu tradycyjnych wartości, kryteriów, odniesień, przyszedł czas powrotu sztuki do zagadnień o charakterze egzystencjalnym, a także do poszukiwań głębszego wymiaru rzeczywistości, sensu, prawdy ${ }^{12}$.

Istotną rolę $\mathrm{w}$ tym okresie odegrał Tadeusz Boruta, który połączył fenomen polskiej sztuki niezależnej lat 80. XX wieku z wyjątkowym doświadczeniem związku kultury z Kościołem i personalizmem chrześcijańskim ${ }^{13}$. Aktywność pedagogiczna profesora Stanisława Rodzińskiego oraz duszpasterska Jana Pawła II i księdza Józefa Tischnera stanowiły istotny czynnik kształtujący postawy twórcze wielu artystów. Piąty etap rozpoczął się w latach 90. i trwa do dzisiaj. Formy instytucjonalnego konsolidowania i analizowania postaw personalnych pojawiły się $\mathrm{w}$ sztuce polskiej już u schyłku lat 80. XX wieku. Biennale Sztuki Sakralnej w Gorzowie Wielkopolskim, którego twórcą był Jerzy Gąsiorek, Częstochowskie Triennale i nieoceniona aktywność Wojciecha Skrodzkiego, Galeria Krypta u Pijarów w Krakowie i Galeria u Jezuitów w Poznaniu, cykl spotkań artystów i teoretyków sztuki - Forum Malarstwa Polskiego w Lesku - to przykłady aktywności zasługujące na uwagę. Interesującym wydarzeniem stała się Galeria Współczesnej Sztuki Sakralnej w Kielcach, która jest rzadkim zjawiskiem w kulturze europejskiej.

11 A. Kępińska, dz. cyt., s. 31-32.

${ }_{12}$ R. Rogozińska, Z btękitem w tle, "Gazeta Malarzy i Poetów” 12 (1996) nr 1, s. 19.

${ }_{13}$ T. Boruta, Personalizm w polskiej sztuce, w: Personalizm polski, Lublin 2008, s. 229. 
Artyści nurtu personalnego w malarstwie polskim ostatnich dwóch dekad stosują wszystkie kategorie estetyczne i środki wyrazu, jakie zaproponował wiek XX. Język form oscyluje między dwoma biegunami: figuratywnym, zbliżonym do formy klasyczno-realistycznej albo inaczej mistycznego realizmu, czego przykładem może być twórczość Tadeusza Boruty i Aldony Mickiewicz, a abstrakcyjnym, dla którego reprezentatywne jest malarstwo Mirosławy Rocheckiej. Ważnym wydarzeniem tego nurtu jest wyjątkowo udana próba wprowadzenia formy ikony w sferę profanum, która w malarstwie Jerzego Nowosielskiego nabrała znamion świętości. W sztuce XX wieku została podtrzymana specyficzna dla niego forma ikonoklazmu i rozbity świat rzeczy. Hans-Georg Gadamer pisał, że „wiek przemysłowy zniszczył rzecz, która została zastąpiona egzemplarzem dość szybko psującym się. W egzemplarzu brak jest tego, co było w rzeczy, czyli tego, co niezastąpione, co uchyla fragment historii, rąbek tajemnicy"14.

Postawy wielu artystów polskich tworzą azyl ocalenia dla tajemnicy „przedmiotu” w obrazie, konsolidują duchową energię w człowieku. W pracach Kiejstuta Bereźnickiego, Mariana Kępińskiego, Janusza Matuszewskiego i wielu innych artystów, których nie sposób tu wymienić, wyczuwa się odnawialny pierwiastek duchowej energii porządkującej. Jerzy Nowosielski stworzył syntetyczną wizję „rzeczywistości metafizycznej", malarską filozofię obrazów ukształtowaną na bazie formy ikony bizantyjskiej, w której sztuka służy do uświęcania, do przetwarzania zła w dobro. Niektóre realizacje Mirosława Bałki i Zofii Dąbrowskiej, obrazy Jacka Waltosia, Mariana Czapli, dynamiczne kompozycje Norberta Skupniewicza, martwe natury Piotra Klugowskiego, cykl pasyjny Eugeniusza Repczyńskiego, malarstwo Andrzeja Okińczyca, ostatnie realizacje malarskie Marka Szarego i Marka Przybyła, malarstwo Rafała Łuszczewskiego oraz prace innych interesujących artystów współczesnych są rodzajem myślenia, rozpoznania, epifanii; zwracają się w kierunku, który wskazuje na zjawisko teurgiczności dzieła sztuki. Dla Mikołaja Bierdiajewa teurgia jest wspólnym z Bogiem kontynuowaniem stworzenia. Teurg w jedności z Bogiem tworzy kosmos, piękno jako byt, teurgia jest sztuką immanentno-religijną, do której powinna prowadzić nowa sztuka, jest cechą sztuki czasów ostatecznych, sztuki końca.

W takim kontekście projekt Mirosława Bałki zrealizowany dla Tate Gallery w Londynie nabiera głębszego znaczenia. Wyłamał się konwencji,

${ }^{14}$ H.-G. Gadamer, Rozum, stowo, dzieje, Warszawa 2009. 
która najczęściej przenika lansowane $\mathrm{w}$ mediach publicznych realizacje plastyczne związane z zewnętrzno-opisowym, ironiczno-ludycznym albo totalnie obrazoburczym myśleniem poprzez sztukę. Realizacja Bałki zdaje się łączyć sztukę z filozofią; z problematyką misterium personae. Artysta stworzył przestrzeń, w którą wprowadził człowieka i w pewnym momencie odciął go od tego wszystkiego, co wiąże się ze światem. Ciemność i noc mają dwojakie znaczenie, wywołują zasadniczo dwie reakcje: lęk i próbę ucieczki albo bezradność, a potem ciszę i skupienie się w sobie. Ta ostatnia reakcja interesuje mnie szczególnie, wiąże się bowiem z mistyką nocy w dziełach św. Jana od Krzyża. Współczesna cywilizacja przez rozświetlenie nocnej przestrzeni miejskiej pozbawia noc ciemności. Człowiek jest niewypoczęty i w związku z tym zawsze na pograniczu, pomiędzy, w taki sposób, że ani dnia nie chłonie proporcjonalnie do swoich potrzeb, ani nocy. Dorota Jarecka w artykule Trojanski kontener Bałki napisała, że wchodząc w realizacje Bałki, doznała rodzaju oświecenia poprzez ciemność, bo paradoksalnie największa ciemność jest blisko najsilniejszego światła. „Bałka najpierw styka widza z konstrukcją, która wydaje się opresyjna, która kojarzy się z więzieniem, ograniczeniem, ciasnotą, ciężarem i militarną lub industrialną dominacją, a potem tę konstrukcję otwiera i pokazuje dosłownie - światło w tunelu. Chyba chce nam powiedzieć o tym, że gdzieś jest jeszcze jakiś inny świat, w którym nikt niczego nam nie narzuca, ani nawet nie tłumaczy, który odbierać możemy tylko własnymi zmysłami i tylko na nich możemy polegać. To nie zagłada, ale odwrotnie - odzyskanie podmiotowości"15, a co za tym idzie - pragnienia (nie mylić z potrzebą).

Nadal ściera się w nas spuścizna metafizyki greckiej z metafizyką judejską, postawa Odysa i Abrahama. Ta druga jest rodzajem konspektu przestrzeni personalnej w kulturze. Emmanuel Levinas, przywołując te dwie postaci, ukazał różnicę między odczuwaniem potrzeby a pragnieniem. W przypadku potrzeby istnieje możliwość i zachodzi fakt „sycenia się". Odczuwanie potrzeb pobudza wyobraźnię, a ta żyje dzięki wspomnieniom. Pragnienie metafizyczne nie jest sycone przez to, co upragnione, ale jeszcze bardziej pogłębiane i przez to nieuchwytne, inne. Abraham $\mathrm{w}$ przeciwieństwie do Odysa szedł w nieznane, bez pomocy pamięci i wyobraźni ${ }^{16}$. Personalizacja przestrzeni sztuki wiąże się z filozofią takiej

15 D. Jarecka, Trojański kontener Bałki, „Gazeta Wyborcza” z 14 października 2009, http://wyborcza.pl/1,75475,7141515,Trojanski_kontener_Balki.html (odczyt z dn. 2.05.2014).

16 J. Tischner, Myślenie wedtug wartości, Kraków 2002, s. 170-174. 
właśnie wędrówki. Nie jest kalejdoskopowym myśleniem postmodernistycznym, ale szukaniem nowych możliwych form wyrazu dla treści, które wiążą się nie tyle $\mathrm{z}$ potrzebą, ile $\mathrm{z}$ pragnieniem. Personalizacja sztuki wiąże się z taką aktywnością człowieka, który przedzierając się przez sferę cielesności i psychologii, ma odwagę czerpać z dynamicznego ducha, bo „Duch daje życie” (J 6,63) ${ }^{17}$.Współczesnemu, poszukującemu człowiekowi nie wystarczy jedynie ładny obraz, bo ten nie ma w sobie siły, aby przebić się przez szum wizualny karmiący ludzką witalność i rozkapryszający ją w taki sposób, że nie tylko infantylnieje, ale także sama siebie zjada. Potrzebna mu sztuka teurgiczna, która czerpie z ducha, która przenikając całego człowieka, ułatwia mu wejście w przestrzeń dla niego przewidzianą, czyli w formę osoby ludzkiej. Osoba Jezusa Chrystusa i Jego nauka spisana dwa tysiące lat temu jest początkiem procesu personalizacji, który $\mathrm{w}$ okresie baroku, w przestrzeni kultury europejskiej, poprzez mistyczne doświadczenia św. Teresy z Avila i św. Jana od Krzyża nabrał dynamizmu. Michał Anioł w późniejszym okresie swojej twórczości poszedł w kierunku ducha. W oczach św. Franciszka na obrazie El Greca odbija się rzeczywistość pozamaterialna i pozaemocjonalna, w Ekstazie św. Teresy nie dominują emocje, ale siła miłości. Św. Jan od Krzyża poznaje Boga, który jest Inny, nie na podobieństwo człowieka. Wiek XX przywalony meteorem materializmu dźwiga się w mocy Ducha i na ramionach wielu świętych ludzi, np. ostatnio beatyfikowanego św. Jana Pawła II. Skutki jego życia duchowo-intelektualno-artystycznego są czytelne nie tylko we wspólnocie Kościoła. Nie mam wątpliwości, że pojawiły się symptomy personalizacji, której wizję roztoczył Teilhard de Chardin, że w czasie istniejącego $\mathrm{w}$ mediach oficjalnych rodzaju obrazoburstwa $\mathrm{w}$ przestrzeni sztuk plastycznych aktywne są i wyraziste postawy artystów, którzy kreują sztuką wokół wartości służących życiu, wywołujących pragnienie wyjścia z pułapki determinizmu natury.

Streszczenie. Człowiek jest duchomaterią; duchem i witalnością. W zależności od tego, którą sferę angażuje bardziej w proces twórczy, powstaje sztuka o znamionach humanizmu, personalizacji bądź depersonalizacji. W przestrzeni polskiej sztuki współczesnej można zauważyć symptomy nowej jakościowo dynamiki estetyczno-duchowej, którą nazywam „personalizacją sztuki” i która wypływa bardziej z podstaw metafizyki judejskiej niż greckiej. Personalizm w polskiej sztuce jest jednym z nurtów sztuki współczesnej, który jest symbiotycznie związany ze środowiskiem

17 Pismo Święte, Poznań-Warszawa 1980, s. 1224. 
kultury chrześcijańskiej (od czasu stanu wojennego) przenikniętej filozofią personalną. Natomiast „personalizacja sztuki” wiąże się ze zjawiskiem bardziej rozległym, niekoniecznie związanym ze środowiskiem chrześcijańskim bezpośrednio. Jest konsekwencją takiej aktywności artystycznej, w której dominuje problematyka związana z podmiotowym podejściem do człowieka. Ta niszowa dynamika estetyczno-duchowa sięga korzeniami aż do okresu Młodej Polski, kiedy to został stworzony naturalny pomost między światem sztuki i religii. Nie jest ona kalejdoskopowym myśleniem postmodernistycznym, ale szukaniem nowych możliwych form wyrazu dla treści, które wiążą się nie tyle z potrzeba, ile z pragnieniem. Coraz bardziej wyraziste są postawy artystów, którzy kreują sztuką wokół wartości służących życiu, wywołujących pragnienie wyjścia z pułapki determinizmu natury mającego swoje odbicie w tzw. produkcji sztuki. Impulsem do tropienia symptomów personalizacji w sztuce polskiej było dzieło Teilharda de Chardin Zarys wszechświata personalistycznego.

Słowa kluczowe: personalizm w sztuce; personalizacja sztuki; sztuka polska; sztuka współczesna.

Summary: Symptoms of Personalisation in Arts. Humans consist of spirit, materiality and vitality. Depending on which of these aspects takes the upper hand, the art created is characterised by humanism, personalisation or depersonalisation. One may observe in the sphere of Polish contemporary art symptoms of ethical and spiritual dynamics that entail new qualities. I refer to this as "personalisation of art", which appears to be stemming more from Jewish metaphysics than from the Ancient Greece. Personalism is one of currents in Polish contemporary art that is, at least since the introduction of the Martial Law in 1981, symbiotically related to the circles of Christian culture which, in turn, is significantly influenced by the philosophy of personalisation. However, the "personalisation of art" entails a much broader phenomenon that is not necessarily directly related to Christian circles. It constitutes a consequence of artistic activity, which is under the sway of issues preoccupied with a personalised approach to humans. This uncommon ethical and spiritual dynamic traces its roots to the period of Young Poland (Młoda Polska), which saw an inception of a bridge between the realms of art and religion. This may not be simply dismissed as a kaleidoscopic, postmodernist approach but is more of an enunciation of searching for new opportunities to formulate structures that are more closely related to longing than they are to needs. Artists' attitudes tilt more openly towards creating art that is preoccupied with life serving values. These justify a need for breaking away from the nature's determinism trap that is reflected by the so-called production of art. Teilhard de Chardin's work: A personalistic universe provided a stimulus for this attempt at investigating the symptoms of personalisation in Polish art.

Keywords: personalism in art; personalisation of art; Polish art, contemporary art. 
